\title{
UPOLITYCZNIENIE SPORTU W XXI WIEKU NA PRZYKŁADZIE LETNICH IGRZYSK OLIMPIJSKICH**
}

\author{
WPROWADZENIE
}

Współcześnie mało kto wątpi we wzajemne przenikanie się sportu i polityki, pomimo idealistycznych koncepcji separacji tych dwóch sfer, lansowanych w szczególności w okresie kształtowania się nowożytnego sportu. Wraz ze znaczącą popularyzacją rywalizacji sportowej stała się ona atrakcyjnym narzędziem realizacji interesów politycznych. Dotyczy to zarówno sfery wewnątrzpaństwowej, jak i międzynarodowej. Jeśli chodzi o tę pierwszą, sport służy do integracji społecznej, kształtowania tożsamości narodowej, a także jest wykorzystywany nierzadko w celach propagandowych jako dowód skuteczności systemu politycznego czy konkretnego rządu. Masowa aktywność fizyczna jest także postrzegana jako element przeciwdziałania chorobom, a niegdyś także jako sposób zwiększenia potencjału obronnego. Szczególnie interesująca jest jednak międzynarodowa polityczna rola sportu. Zwycięstwa w sporcie służą do komunikowania potencjału danego państwa oraz zdobywania prestiżu międzynarodowego. Dzięki organizacji imprez sportowych państwa mogą kształtować swój międzynarodowy wizerunek, wzmacniając własną soft power. Podobną rolę mogą odgrywać wymiany sportowe czy sportowa pomoc rozwojowa. Sport może także być wykorzystywany jako narzędzie prowadzenia stosunków z innymi państwami. Poprzez kontakty sportowe państwa starają się zbliżyć z innymi krajami, aczkolwiek sport może także służyć jako narzędzie wyrażania niezadowolenia z polityki innego państwa, czego wyrazem były liczne w historii bojkoty sportowe oraz sportowa izolacja państw. Polityczno-dyplomatyczną rolę może również mieć udział w międzynarodowej rywalizacji sportowej - jest on istotny dla państw o kwestionowanej podmiotowości międzynarodowej. Jak więc widać, związki pomiędzy sportem a polityką są bardzo wyraźne. Imprezy

\footnotetext{
* Dr Micha£ Marcin Kobierecki - Katedra Teorii Polityki i Myśli Politycznej, Wydział Studiów Międzynarodowych i Politologicznych, Uniwersytet Łódzki, e-mail:mkobierecki@uni.lodz.pl

** Badanie sfinansowane przez Narodowe Centrum Nauki” w ramach projektu nr 2015/19/D/HS5/00513
} 
sportowe, za sprawą swojej wielkiej popularności, stają się także celem zamachów terrorystycznych. Istotna staje się współcześnie także polityczna rola międzynarodowych organizacji sportowych takich jak Międzynarodowy Komitet Olimpijski, które w wielu sytuacjach przyjmują rolę aktorów dyplomatycznych.

Igrzyska olimpijskie, szczególnie ich letnia odmiana, są uważane za najważniejszą imprezę sportową współczesnego świata. To właśnie wokół nich uformowała się cała struktura międzynarodowego sportu, zaś zwycięstwo w nich jest największym wyczynem dla reprezentantów większości dyscyplin sportowych. Nie może dziwić, iż także upolitycznienie sportu jest podczas igrzysk olimpijskich szczególnie wyraźne. Często wskazuje się, że okres najbardziej intensywnego upolitycznienia międzynarodowego sportu przypadł na okres Zimnej Wojny, kiedy to rywalizacja na igrzyskach olimpijskich stała się jedną z aren konfrontacji mocarstw. Wskazuje się także na igrzyska olimpijskie w Berlinie w 1936 roku, które Trzecia Rzesza starała się wykorzystać pod względem propagandowym. Jednak w rzeczywistości koniec zimnej wojny wcale nie oznaczał końca upolitycznienia sportu, które możemy obserwować do chwili obecnej.

Celem niniejszego artykułu jest przegląd tego, w jaki sposób dochodziło do upolitycznienia sportu podczas letnich igrzysk olimpijskich w XXI wieku, a zatem podczas igrzysk olimpijskich w Atenach w 2004 roku, Pekinie w 2008 roku, Londynie w 2012 roku oraz w Rio de Janeiro w 2016 roku. W artykule zostanie podjęta próba odpowiedzi na pytanie badawcze, czy we współczesnym, multilateralnym świecie sport w dalszym ciągu odgrywa istotną rolę polityczną, podobnie jak miało to miejsce w okresie zimnej wojny.

\section{ATENY 2004}

Grecja to kolebka igrzysk olimpijskich. To właśnie do igrzysk olimpijskich w starożytnej Grecji nawiązał Pierre de Coubertin tworząc nowożytny ruch olimpijski. To właśnie w stolicy Grecji odbyły się w 1896 roku pierwsze nowożytne igrzyska olimpijskie. Nie może dziwić, że Grecy za punkt honoru obrali sobie organizację igrzysk także w 1996 roku, w stulecie pierwszych nowożytnych igrzysk. Tymczasem MKOl przyznał prawo ich organizacji położonej w Stanach Zjednoczonych Atlancie. Wywołało to liczne kontrowersje i sprzeciwy ze strony Greków. Grecka minister kultury określiła wręcz tę decyzję jako „zwycięstwo Coca-Coli nad Partenonem"1. Ateny nie otrzymały prawa organizacji igrzysk również w 2000 roku, jednak MKOl ostatecznie zdecydował się przyznać Grekom igrzyska mające się odbyć w roku 2004. Biorąc pod uwagę, że organizatorzy igrzysk w Atenach

\footnotetext{
${ }^{1}$ Ateny 2004, PKOl, http://www.olimpijski.pl/pl/251, ateny-2004.html, dostęp 28.02.2017.
} 
zdążyli z przygotowaniem obiektów niejako „w ostatniej chwili”, nie mogą dziwić wątpliwości członków Międzynarodowego Komitetu Olimpijskiego odnośnie organizacji igrzysk właśnie w stolicy Grecji.

$\mathrm{W}$ czasie przygotowań igrzysk w Atenach kluczowym zagadnieniem, nie uwzględnionym na etapie planowania, było bezpieczeństwo. Co prawda uwaga organizatorów igrzysk dotycząca kwestii zabezpieczenia imprezy wzrosła znacząco już trzy dekady wcześniej, na skutek zamach terrorystycznego na sportowców izraelskich podczas igrzysk w Monachium, jednak to zamachy terrorystyczne w Stanach Zjednoczonych 11 września 2001 roku wymusiły na organizatorach ateńskich igrzysk zupełnie inne podejście do sprawy. Obawy o bezpieczeństwo były szczególnie silne także ze względu na szereg nieudanych zamachów terrorystycznych, do których dochodziło w Grecji w przeciągu kilku miesięcy przed igrzyskami. Efektem tego, na zapewnienie bezpieczeństwa podczas igrzysk organizatorzy przeznaczyli około miliarda dolarów, a konkretne działania obejmowały m.in. wykorzystanie dziesiątek tysięcy wyszkolonych osób, zabezpieczenia lotniczego, działań wywiadowczych, zabezpieczenia morskiego, a nawet pomocy ze strony $\mathrm{NATO}^{2}$. Potencjalnym celem greckich terrorystów miało być niedopuszczenie do przyjazdu „,kapitalistów i zachodnich imperialistów" na igrzyska ${ }^{3}$. Jeśli domniemania odnośnie potencjalnego celu ewentualnych zamachowców były słuszne, to do pewnego stopnia udało im się je spełnić. Wskazuje się bowiem, iż z w uwagi na zagrożenie terrorystyczne część kibiców rezygnuje z uczestniczenia w imprezach sportowych, natomiast właśnie podczas igrzysk w Atenach w 2004 roku zanotowano niższą niż oczekiwano frekwencję kibiców ${ }^{4}$.

Polityczność igrzysk olimpijskich w Atenach można także dostrzec w kontekście stosunków pomiędzy Koreą Północną i Południową, a więc państwami podzielonymi na skutek wojny koreańskiej, które formalnie w dalszym ciągu pozostają w stanie wojny. W okresie prowadzenia przez Koreę Południową tzw. Słonecznej Polityki między krajami dochodziło do szeregu wymian i form współpracy w dziedzinie sportu. Zatem podczas igrzysk w Atenach reprezentacji obydwu krajów maszerowali wspólnie podczas ceremonii otwarcia, wykorzystując zarazem wspólną flagę. Podobnie było z resztą podczas odbywających się cztery lata wcześniej igrzysk w Sydney, a także dwa lata później igrzysk zimowych w Turynie ${ }^{5}$ Ten bez wątpienia polityczny symbol był jednym z dowodów na polityczną rolę igrzysk

2 T. Taylor, K. Toohey, Perceptions of Terrorism Threats at the 2004 Olympic Games: Implications for Sport Events, „Journal of Sport \& Tourism” 2007, nr 2(12), s. 103, K. Toohey, T. Taylor, Mega Events, Fear, and Risk: Terrorism at the Olympic Games, „Journal of Sport Management”, 2008, nr 22, s. 462.

${ }^{3}$ Y. Galily, I. Tamir, M. Levy, The games must go on? The influence of terror attacks on hosting sporting events in Israel, „Israel Affairs” 2012, vol. 18, nr 4, s. 632.

${ }^{4}$ T. Taylor, K. Toohey, Perceptions of Terrorism..., s. 100.

${ }^{5}$ Z. Mateša, Wydarzenia sportowe jako kluczowy element przelamywania barier, [w:] Sport i Dyplomacja, Polski Komitet Olimpijski, Warszawa 2015, s. 28. 
olimpijskich. Już bowiem twórca nowożytnego olimpizmu Pierre de Coubertin wierzył, że za ich sprawą możliwe jest promowanie pokoju międzynarodowego, zgodnie z zaproponowaną przez niego ideą neoolimpizmu ${ }^{6}$. Co prawda trwałego zbliżenia pomiędzy tymi skonfliktowanymi krajami nie udało się osiągnąć, jednak i w tym przypadku polityczność igrzysk olimpijskich jest wyraźnie dostrzegalna.

\section{PEKIN 2008}

Igrzyska olimpijskie w Pekinie w 2008 roku przez wielu uważane są za najbardziej upolitycznione w ostatnich latach. Ich organizacja miała silny wymiar polityczny już od etapu ich koncepcji, miały one bowiem służyć kształtowaniu pożądanego, międzynarodowego wizerunku Chin na świecie. Nie bez znaczenia był także fakt, iż Chiny są krajem niedemokratycznym, łamiącym prawa człowieka, bowiem historia pokazuje, iż igrzyska organizowane przez państwa o takich reżimach bardzo często stają się arenami upolitycznienia sportu. Po raz pierwszy Chiny ubiegały się o organizację letnich igrzysk olimpijskich w 2000 roku. Aplikację złożono na początku 1991 roku$^{7}$, jednak wówczas nie udało się Chińczykom otrzymać prawa goszczenia tej imprezy. Wskazuje się, iż na odrzucenie kandydatury Pekinu w pewnym stopniu wpłynęła międzynarodowa krytyka rządu Chin w związku z rozbiciem ruchu demokratycznego w 1989 roku $^{8}$. Przeciwnicy kandydatury Pekinu podnosili także kwestie Tybetu, praw człowieka, dysydentów politycznych, braku poszanowania dla indywidualizmu i rządów prawa oraz stanu stosunków z Tajwanem 9 . Do ponownego ubiegania się przez Pekin o organizację letnich igrzysk doszło osiem lat później. Tym razem zostało ono zwieńczone sukcesem i decyzją Sesji MKOl w Moskwie w lipcu 2001 roku to Pekin wybrano gospodarzem igrzysk w 2008 roku.

Dla Chińczyków organizacja igrzysk stanowiła przede wszystkim okazję do kształtowania własnego wizerunku międzynarodowego. Istnieje bardzo bogata literatura na temat tego, jakie komunikaty organizatorzy igrzysk chcieli przekazać. Wskazuje się zatem na chęć zademonstrowania zintegrowania Chin z rodziną

${ }^{6}$ Z. Krawczyk, Sport in changing Europe, w: Sports Involvement in Changing Europe, red. J. Kosiewicz, K. Obodyński, Rzeszów 2004, s. 12.

${ }^{7}$ Sydney Organising Committee for the Olympic Games, Official Report of the XXVII Olympiad. Preparing of the Games, vol. I, Sydney 2001, s. 14.

${ }^{8}$ A-M. Brady, The Beijing Olympics as a campaign of mass distraction, w: China's Thought Management, red. A-M. Brady, Abingdon 2012, s. 15.

9 A. Lai Lee, Did the Olympics help the nation branding of China? Comparing public perception of China with the Olympics before and after the 2008 Beijing Olympics in Hong Kong, „Place Branding and Public Diplomacy” 2010, vol. 6, nr 3, s. 209. 
narodów świata ${ }^{10}$, jednak zdecydowanie najczęściej podkreślaną motywacją Chińczyków było pokazanie kraju jako światowej potęgi. Badacze wskazują także na chęć pokazania odrodzenia chińskiej cywilizacji oraz podniesienia Chin do statusu jednej z głównych potęg światowych ${ }^{11}$. „Chiny w końcu stały się nowoczesną superpotęgą" - takie było kluczowe przesłanie, skierowane zarówno do świata zewnętrznego, jak i do samych Chińczyków ${ }^{12}$. W literaturze przedmiotu igrzyska w Pekinie często określane są jako „impreza wychodzenia z ukrycia” (w języku angielskim coming out party), podkreślająca boom gospodarczy, jaki Chiny przeżywały w ostatnich latach ${ }^{13}$.

Chińskie komunikaty międzynarodowe przekazywane poprzez igrzyska w Pekinie dotyczyły ponadto chęci pokazania „nowych Chin”, które „dołączyły do nowoczesności”"14, posiadają rozwiniętą technologię i wyrafinowaną infrastrukturęel. Twierdzi się ponadto, iż celem igrzysk było rozwiewanie międzynarodowych obaw związanych z rosnącą potęgą polityczną, gospodarczą i militarną Chin ${ }^{16}$. Problem dla Chińczyków w kształtowaniu międzynarodowego wizerunku poprzez igrzyska stanowił fakt, że z jednej strony chciano zadziwić świat potęgą kraju, z drugiej zaś obawiano się, aby nie „przestraszyć świata”, zgodnie z założeniem polityki wizerunkowej Chin, iż wzrost jej potęgi ma charakter pokojowy a Chiny nie stanowią dla nikogo zagrożenia ${ }^{17}$. Wydaje się to być zbieżne z międzynarodowymi interesami Chin, których wielki rozwój opiera się przede wszystkim na międzynarodowej wymianie gospodarczej.

${ }^{10}$ L. Qing, Encoding the Olympics - Visual Hegemony? Discussion and Interpretation on Intercultural Communication in the Beijing Olympic Games, „The International Journal of the History of Sport" 2010, vol. 27, nr 9-10, s. 1830.

${ }^{11}$ Y-N. Lu, The Representation of the 2008 Beijing Olympic Games: The Rise of China's Soft Power, w: China's Quiet Rise. Peace Through Integration, red. B. Guo, C-C. Teng, Lanham 2011, s. 29, J. A. Mangan, H.-D. Kim, A. Cruz, G.-H. Kang, Rivalries: China, Japan and South KoreaMemory, Modernity, Politics, Geopolitics - and Sport, „The International Journal of the History of Sport" 2013, vol. 30, nr 10, s. 1131.

${ }^{12}$ H. Bonde, Sport, the Olympics and Politics: European Responses to Beijing 2008, „The International Journal of the History of Sport" 2009, vol. 26, nr 10, s. 1558.

${ }_{13}$ V. D. Cha, Beyond the Final Score. The Politics of Sport in Asia, New York 2009, s. 3.

${ }^{14}$ G. Zeng, F. Go, C. Kolmer, The impact of the 2008 Summer Olympic Games on Beijing's and Chinas's image, w: Global Sport Marketing. Contemporary issues and practice, red. M. Desbordes, A. Richelieu, London 2012, s. 63, K. Latham, Unimagined China: Media, Technologies and the Fragmentation of National Olympic Audiences, „The International Journal of the History of Sport” 2012, vol. 29, nr 16, s. 2312.

${ }^{15}$ G. A. Pigman, International Sport and Diplomacy's Public Dimension: Governments, Sporting Federations and the Global Audience, „Diplomacy \& Statecraft” 2014, nr 25, s. 101.

16 A-M. Brady, The Beijing Olympics..., s. 17.

${ }_{17}$ P. H. Gries, H. M. Crowson, T. Sandel, The Olympic Effect on American Attitudes towards China: beyond personality, ideology, and media exposure, „Journal of Contemporary China” 2010, nr 19 (64), s. 214. 
Wszystkie powyższe cele miały przede wszystkim wymiar zewnętrzny, jednak igrzyska miały także oddziaływać na samych Chińczyków. Ich rolą było bowiem także konsolidowanie legitymizacji Komunistycznej Partii Chin. Wskazuje się $\mathrm{z}$ resztą, iż pod tym względem igrzyska odniosły większy sukces niż w wymiarze zewnętrznego budowania wizerunku ${ }^{18}$. Uważa się jednak, iż podczas samych igrzysk większy priorytet został nadany komunikowaniu do zewnętrznych odbiorców ${ }^{19}$. Igrzyska w Pekinie mogą być zatem uznane za niezwykle charakterystyczny przykład wizerunkowej dyplomacji sportowej.

Cele wizerunkowe igrzysk Chińczycy starali się osiągnąć na szereg sposobów. Prowadzono np. swoistą akcję , cywilizowania” Chińczyków, aby godnie zaprezentowali się gościom. Przykładowo przed igrzyskami w Pekinie uruchomiono masowe szkolenia z etykiety dla zwykłych mieszkańców miasta. Chodziło o ograniczenie takich nawyków, jak plucie na ulice, wpychanie się do kolejki, śmiecenie, a także zachęcano do pomocy osobom w potrzebie. Uczono także jak w kulturalny sposób kibicować, wykorzystując do tego reklamy telewizyjne ${ }^{20}$. Stawiano także na efektowną infrastrukturę sportową, która miała świadczyć o możliwościach Chińskiej Republiki Ludowej. Zbudowano 400 mil nowych dróg ekspresowych, cztery nowe linie metra, nowy terminal na lotnisku, 37 nowych stadionów w sześciu miastach ${ }^{21}$. Spośród inwestycji sportowych na szczególną uwagę zasługują stadion olimpijski „Ptasie Gniazdo” oraz pływalnia „Wodna Kostka”, które stały się symbolami igrzysk. Wszystkie te inwestycje zostały ukończone na czas lub nawet przed czasem ${ }^{22}$, co stanowiło kontrast chociażby wobec igrzysk w Atenach. Chińczycy czynili także kroki w celu poprawy stanu środowiska naturalnego w Pekinie, np. poprzez przeniesienie lub czasowe zamknięcie części fabryk ${ }^{23}$ czy intensywne zalesianie ${ }^{24}$. Kluczowa w szerszym procesie komunikowania międzynarodowego poprzez igrzyska w Pekinie była ceremonia otwarcia, pełna symboliki i efektownych motywów, jak cytaty z Konfucjusza niesione przez 3000 artystów, 2008 maszerujących dzieci, które miały symbolizować jedność ludzkiej rasy i nadzieję na harmonijną przy-

18 R. Tomlinson, O. Bass, T. Bassett, Before and after the vuvuzela: identity, image and megaevents in South Africa, China and Brazil, „South African Geographical Journal” 2011, vol. 93, nr 1, s. $43-44$.

19 S. Brownell, The Beijing Olympics as a Turning Point? China's First Olympics in East Asian Perspective, „The Asia-Pacific Journal. Japan Focus” 2009, vol. 7, zeszyt 23, nr 4, s. 3.

20 A-M. Brady, The Beijing Olympics..., s. 24-25.

21 V. D. Cha, Beyond the Final..., s. 111.

${ }^{22}$ International Olympic Committee, Factsheet. Beijing Facts and Figures, August 2009, s.2, https://www.olympic.org/olympic-legacy/ /media/A8264DD681D34B459B026CBD6FFD4D78.ashx, dostęp 10.10.2016, BOCOG, Preparation for the Games: New Beijing Great Olympics. Official Report of the Beijing 2008 Olympic Games, vol. III, s. 30.

23 D. Thompson, Beijing Olympics: More at Stake than Gold Medals, ,chinabusinessreview. com", January-February 2008, s. 41.

24 V. D. Cha, Beyond the Final..., s. 115. 
szłość ${ }^{25}$. Wielkie wrażenie robiły występ masowe występy 14.000 osób, a także efekty specjalne, jakie zastosowano. Ceremonię Anne-Marie Brady porównała do oglądanej przez około dwa miliardy ludzi premiery produktu, którym w tym przypadku były Nowe Chiny ${ }^{26}$, co biorąc pod uwagę cele wizerunkowe związane z organizacją igrzysk oraz przebieg ceremonii wydaje się trafnym porównaniem.

Wizerunkową rolę stanowiła dla Chin nie tylko organizacja igrzysk, ale także występy chińskich sportowców w ich trakcie. Miały one stanowić część potwierdzania tożsamości kraju, którą igrzyska miały sportretować ${ }^{27}$. W tym kontekście władzom chińskim zależało nie tylko na zwycięstwie w klasyfikacji medalowej, ale także na pokonaniu Stanów Zjednoczonych, zarówno jeśli chodzi o tabelę medalową, jak i w bezpośrednich starciach. Było to związane z zaangażowaniem USA przeciwko przyznaniu Pekinowi igrzysk w 2000 roku, zaś po wyborze tego miasta na gospodarza igrzysk w 2008 roku właśnie ze Stanów Zjednoczonych słychać było głosy o potrzebie ich zbojkotowania ${ }^{28}$. Obok bardziej doraźnej motywacji należy ponadto wskazać symboliczny potencjał ewentualnego pokonania Stanów Zjednoczonych. Kraj ten stanowił bowiem największą potęgę sportową, ale co jeszcze ważniejsze, uznawany jest za najpotężniejsze mocarstwo polityczne i gospodarcze. Czyż można zatem wyobrazić sobie lepszy sposób na wizerunkowe wykreowanie się na potęgę, niż pokonanie największe mocarstwo na igrzyskach olimpijskich?

Upolitycznienie igrzysk olimpijskich w Pekinie związane było nie tylko z ich rolą wizerunkową, ale także $\mathrm{z}$ wieloma kontrowersjami natury politycznej, do jakich doszło w związku z nimi. Chodziło przede wszystkim o protesty, do jakich dochodziło na całym świecie, w związku z polityką prowadzoną przez chiński rząd. W trakcie sztafety olimpijskiej dochodziło do wielu protestów i musiała być ona ochraniana przez służby bezpieczeństwa poszczególnych krajów. Doszło to tego, że konieczne było odwołanie odcinka sztafety w Paryżu po tym, jak zaatakowano jej uczestniczkę - jeżdżącą na wózku inwalidzkim chińską szermierkę paraolimpijską Jin Jing. Zdarzenie to stanowiło dla Pekinu symbol ataku sił antychińskich i pro-tybetańskich na pokojowy naród chiński ${ }^{29}$.

Wskazane wyżej problemy związane ze sztafetą olimpijską stanowiły jedynie fragment trudności, przed jakimi stawali organizatorzy igrzysk i władze Chin. Międzynarodowy sprzeciw rozpoczął się na dobre kiedy gwiazda Hollywood Mia Farrow otwarcie skrytykowała popieranie przez Chiny reżimu w Sudanie i nawo-

25 J. A. Mangan, G. Ok, Beijing 2008: Symbolic Hegemonic Assertion? South Korean Media Reactions and Responses to the Chinese Olympics, „The International Journal of the History of Sport" 2010, vol. 27, nr 14-15, s. 2442.

${ }^{26}$ A-M. Brady, The Beijing Olympics..., s. 26.

27 V. D. Cha, Politics and the Olympic Transaction: Measuring China's Accomplishments, „The International Journal of the History of Sport” 2010, vol. 27, nr 14-15, s. 2364.

${ }^{28}$ J. deLisle, "One World, Different Dreams": The Context to Define the Bijing Olympics, w: Owing the Olympics. Narratives of the New China, red. M. E. Price, D. Dayan, Ann Arbor 2008, s. 32.

${ }^{29}$ H. Bonde, Sport, the Olympics..., s. 1565. 
ływała do bojkotu igrzysk ${ }^{30}$. Jednym z efektów tego było wycofanie się Stevena Spielberga z reżyserowania ceremonii otwarcia imprezy. Innymi obok popierania reżimu w Sudanie krytykowanymi aspektami były współpraca rządu Chin z reżimami politycznymi Myanmar, Korei Północnej, Zimbabwe, a także stłumienie powstania $\mathrm{w}$ Tybecie $\mathrm{e}^{31}$. Jednym $\mathrm{z}$ bardziej widocznych medialnie efektów owych protestów była decyzja niektórych przywódców politycznych, aby nie uczestniczyć w ceremonii otwarcia igrzysk, przede wszystkim kanclerz Niemiec Angeli Merkel i premiera Wielkiej Brytanii Gordona Browna ${ }^{32}$, aczkolwiek ten drugi poinformował o odstąpieniu od udziału w ceremonii otwarcia z wyprzedzeniem twierdząc, że nie stanowiło to bojkotu, a także wziął udział w ceremonii zakończenia igrzysk ${ }^{33}$. Ostatecznie na ceremonii otwarcia obecni byli przedstawiciele ponad 100 państw. Sytuację tę liderzy chińscy starali się zarazem wykorzystać dyplomatycznie, aranżując spotkania z owymi gośćmi ${ }^{34}$. Biorąc wszystkie te elementy pod uwagę nie może dziwić, że igrzyska w Pekinie uważane są za najbardziej upolitycznione w ostatnim czasie. Co ciekawe, Pekin będzie ponownie gościł igrzyska olimpijskie w 2022 roku, tym razem w ich zimowej odmianie.

\section{LONDYN 2012}

Londyn jako jedyne miasto gościł igrzyska olimpijskie aż trzykrotnie, przy czym pierwsze dwa przypadki miały miejsce w sytuacjach kryzysowych dla ruchu olimpijskiego. Igrzyska w 1908 roku Londyn zorganizował po tym, jak wycofał się z tego Rzym, natomiast w 1948 roku igrzyska odbyły się w Londynie m.in. z uwagi na powojenne problemy i trudności, jakie zniszczone państwa europejskie miałyby z wysłaniem reprezentacji na inny kontynent. Igrzyska w Londynie w 2012 roku nie miały takiego kontekstu. Generalnie wymiar polityczny tych igrzysk był znacznie mniej wyraźny niż w przypadku odbywających się cztery lata wcześniej igrzysk w Pekinie. Tym niemniej igrzyskom w Londynie także można przypisać polityczne i dyplomatyczne znaczenie, związane z chęcią wykorzystania faktu

${ }^{30}$ F. Hong, L. Zhouxiang, The Politicisation of Sport in Modern China. Communists and Champions, London 2013, s. 157.

${ }^{31}$ H. Bonde, Sport, the Olympics..., s. 1562.

${ }^{32}$ C. Pan, Problematizing "Constructive Engagement" in EU-China Policy, w: Europe and China: Strategic Partners or Rivals?, red. R. Vogt, Hong Kong 2012, s. 38.

${ }^{33}$ I. d'Hooghe, The Limits of China's Soft Power in Europe. Beijing's Public Diplomacy Puzzle, The Hague 2010, s.27.

${ }^{34}$ Q. Zhang, Sports Diplomacy: The Chinese Experience and Perspective, „The Hague Journal of Diplomacy” 2013, nr 8, s. 227. 
ich organizacji przez brytyjski rząd, w celu kształtowania międzynarodowego wizerunku tego kraju.

Londyn nie należał do faworytów jeśli chodzi otrzymanie prawa organizacji igrzysk, zrobił jednak dobre wrażenie podczas wizyty Komisji Ewaluacyjnej MKOl - szczególnie w związku z możliwością szybkiego dostania się do miejsc rozgrywek z centrum Londynu koleją ${ }^{35}$. Podczas Sesji MKOl w Singapurze w 2005 roku wybierano spomiędzy Paryża, Londynu, Nowego Jorku, Moskwy i Madrytu. W czwartej turze pozostały Paryż i Londyn, a głosowanie zakończyło się zwycięstwem stolicy Wielkiej Brytanii 54 do $50^{36}$. Wskazuje się, że do ostatecznego wyniku zauważalnie przyczynił się premier Wielkiej Brytanii Tony Blair, który przez kilka dni przed podjęciem przez MKOl decyzji podczas Sesji w Singapurze lobbował za takim rozwiązaniem - w przeciwieństwie do pewnego siebie prezydenta Francji Jacquesa Chiraca, który przybył do Singapuru w ostatniej chwili ${ }^{37}$. Już zatem na etapie aplikowania o prawo organizacji igrzysk w Londynie dostrzec można ich polityczny kontekst, ze względu na silne zaangażowanie się przywódców państw. Sytuacja taka jeśli chodzi o ubieganie się o prawo organizacji największych imprez sportowych współcześnie staje się z resztą coraz częstsza. Do polityków, którzy szczególnie silnie angażowali się we wspieranie kandydatur do goszczenia wydarzeń sportowych zalicza się chociażby prezydenta Rosji Wladimira Putina.

Niespodziewane przyznanie Londynowi prawa organizacji igrzysk oznaczało dla Brytyjczyków pewne problemy. Związane były one chociażby z koniecznością zapewnienia bezpieczeństwa - w związku z zagrożeniem terrorystycznym. Należy bowiem pamiętać, iż dzień po ogłoszeniu, iż Londyn będzie gospodarzem igrzysk olimpijskich, doszło w tym mieście do zamachów terrorystycznych w autobusach miejskich i metrze ${ }^{38}$. Problem zagrożenia terrorystycznego dotyczącego imprez sportowych to kolejny związany z igrzyskami w Londynie aspekt zbliżający światy sportu i polityki. Szczęśliwie jednak w ostatnich latach, głównie za sprawą wielkiej uwagi, jaką organizatorzy zawodów sportowych przykładają do kwestii bezpieczeństwa, udawało się uniknąć zamachów terrorystycznych podczas samych igrzysk.

Wiele wskazuje na to, że do czasu przyznania organizacji igrzysk olimpijskich w 2012 roku Londynowi brytyjskie Ministerstwo Spraw Zagranicznych i Wspólnoty Narodów (FCO) raczej nie traktowało sportu jako ważnego elementu swojego dyplomatycznego repertuaru, zaś zaangażowanie w sport ograniczało się do wspierania wyjazdów sportowców na zagraniczne zawody ${ }^{39}$. Wskazuje się także,

35 J. Horne, G. Whannel, Understanding the Olympics, London 2012, s. 16.

${ }^{36}$ Londres 2012. Rapport officiel des Jeux Olympiques, vol 1, London 2012, s. 40.

${ }^{37}$ A. Tomlinson, Lording It. London and the getting of the Games w: Watching the Olympics. Politics, power and representation, red. J. Sugden, A. Tomlinson, London 2012, s. 6.

${ }^{38}$ A. Bairner, G. Molnar, The politics of the Olympics: An Introduction w: The Politics of the Olympics. A Survey, red. A. Bairner, G. Molnar, London 2010, s. 8.

39 J. Grix, B. Houlihan, Sports Mega-Events as Part of a Nation's Soft Power Strategy: The Cases of Germany (2006) and the UK (2012), „The British Journal of Politics and International 
iż chęć wizerunkowego wykorzystania igrzysk w Londynie przez rząd brytyjski pojawiła się dopiero po ich przyznaniu Londynowi ${ }^{40}$. Wówczas Tony Blair postanowił wzmocnić kosmopolityczny motyw wizerunkowy, który wykorzystywano także na etapie aplikacji o igrzyska, poprzez pokazanie Londynu jako otwartego, wielorasowego, wieloreligijnego, wielokulturowego miasta, które jest $\mathrm{z}$ tego dumne $^{41}$. Igrzyska stały się więc dla rządu brytyjskiego platformą przekazywania kluczowych informacji odnośnie XXI-wiecznej Wielkiej Brytanii - do szerokich rzesz odbiorców na całym świecie, którzy nie byliby zainteresowani tradycyjnymi kwestiami stosunków międzynarodowych, jak określił to brytyjski dyplomata Sir Nigel Sheinwald ${ }^{42}$. Jednocześnie, stały się one dla Brytyjczyków okazją do zredefiniowania tożsamości narodowej zarówno wewnętrznie, jak i w odniesieniu do jej postrzegania przez resztę świata. Chciano pod tym względem nawiązywać do brytyjskiego włączenia społecznego ${ }^{43}$.

FCO nakreśliła swoje cele związane z igrzyskami w Londynie w 2011 roku. Stwierdzono wówczas, iż powinno się wykorzystać szansę związaną z rozprzestrzenianiem na świecie wizerunku nowoczesnej, XXI-wiecznej Wielkiej Brytanii, jaką dają igrzyska ${ }^{44}$. Analizując międzynarodowy wizerunek Wielkiej Brytanii w FCO zauważono, iż kraj ten jest postrzegany przez zagraniczną publikę jako „uczciwy, innowacyjny, różnorodny, pewny siebie i stylowy, ale także arogancki, wyniosły, staroświecki i zimny". W związku z tym zdecydowano, iż igrzyska w Londynie mają kreować bardziej preferowany obraz Wielkiej Brytanii jako nowoczesnej, otwartej (gościnnej, zróżnicowanej, tolerancyjnej), połączonej ze światem (politycznie, geograficznie, handlowo i pod kątem podróży), kreatywnej i dynamicznej. Wskazywano przy tym jednocześnie, iż Londyn może pod względem wizerunkowym skorzystać bardziej niż reszta Wielkiej Brytanii. Zauważono zarazem, iż organizacja igrzysk w Londynie może stanowić kluczową szansę na powyższe poprawienie wizerunku ${ }^{45}$. Poza podkreślaniem nowych elementów jeśli chodzi o pożądany wizerunek Wielkiej Brytanii nie rezygnowano także z wyko-

Relations" 2014, vol. 16, s. 584.

${ }^{40}$ J. Grix, P. M. Brannagan, B. Houlihan, Interrogating States' Soft Power Strategies: A Case Study of Sports Mega-Events in Brazil and the UK, „Global Society” 2015, vol. 29, nr 3, s. 472.

${ }^{41}$ M. R. G. Pope, Public diplomacy, international news media and London 2012: cosmopolitanism $^{T M}$, „Sport in Society” 2014, vol. 17, nr 9, s. 1119.

42 J. S. Rofe, It is a squad game: Manchester United as a diplomatic non-state actor in international affairs, „Sport in Society” 2014, s. 8.

${ }^{43}$ I. MacRury, G. Poynter, 'Team GB' and London 2012: The Paradox of National and Global Identities, „The International Journal of the History of Sport” 2010, vol. 27, nr 16-18, s. 2959.

${ }^{44}$ House of Commons Foreign Affairs Committee, FCO Public Diplomacy: The Olympic and Paralympic Games 2012, Second Report of Session 2010-11, London 2011, s. 20.

${ }^{45}$ B. Houlihan, T-C. Tan, J. Park, The national government perspective, w: Routledge Handbook of Sports Event Management, red. M. M. Parent, J-L. Chappelet, London 2015, s. 296-297, J. Grix, B. Houlihan, Sports Mega-Events..., s. 583, J. Horne, B. Houlihan, London 2012, w: Leveraging Legacies from Sports Mega-Events. Concepts and Cases, red. J. Grix, London 2014, s. 112. 
rzystywania aspektów, z którymi kraj ten był już wcześniej pozytywnie kojarzony. Zjednoczone Królestwo miano bowiem promować jako czołowy kraj świata z dziedzictwem, które miało być podkreślane poprzez wybór miejsc rozgrywania poszczególnych rozgrywek. Kluczowymi motywami były potencjalnie sprzeczne dziedzictwo i włączeniowa młodzieżowa nowoczesność, co było już widoczne podczas ceremonii zakończenia igrzysk w Pekinie, kiedy to tradycyjny londyński autobus przywiózł wielokulturową grupę tancerzy hip hop ${ }^{46}$.

Osiągnięcie powyższych celów wizerunkowych miało kilka motywacji. Z jednej strony, w sposób typowy dla dyplomacji publicznej, wizerunkowe korzyści związane z organizacją igrzysk w Londynie miały w intencji FCO prowadzić do „otwierania drzwi" i uzyskiwania wpływu na kluczowe jednostki i grupy w poszczególnych krajach, w ramach realizacji brytyjskich interesów ${ }^{47}$. Z drugiej strony chodziło o uzyskanie korzyści o charakterze bardziej komercyjnym i gospodarczym. Zwiększenie ilości turystów chciano osiągnąć poprzez kreowanie wizerunku Wielkiej Brytanii jako „Kraju Sztuki” i „Kraju Kreatywności”. Starano się ponadto budować na nowo markę państwa jako czołowego narodu świata pod względem politycznym i gospodarczym, jako kraju edukacji, kolebki demokracji oraz dobrego miejsca do lokowania inwestycji ${ }^{48}$. Wg Jonathana Grixa i Barry'ego Houlihana najważniejszą motywacją było właśnie przyciągnięcie inwestycji i partnerów biznesowych, prawdopodobnie ponieważ nie istniała konieczność przeciwdziałania negatywnemu postrzeganiu kraju. Wskazuje się bowiem, że międzynarodowy wizerunek Wielkiej Brytanii był bardzo dobry, konieczne stało się jedynie jego pewne „ulepszenie”. W związku z tym pojawiały się jednocześnie obawy, że biorąc pod uwagę dobrą markę brytyjską igrzyska w Londynie, w większym stopniu mogły jej zaszkodzić - w przypadku ich porażki organizacyjnej, niż poprawić gdyby zakończyły się sukcesem $^{49}$.

Efekt wizerunkowy igrzysk w Londynie w dużej mierze miał zostać osiągnięty poprzez odpowiednio przygotowaną ceremonię otwarcia. Jej oglądalność szacowana jest na 900 milionów ludzi. Była ona mniejsza niż w przypadku igrzysk w Pekinie, jednak i tak świadczy o jej potencjale jeśli chodzi o działania wizerunkowe. Za jej przygotowanie odpowiadał reżyser Danny Boyle. Widowisko miało przedstawić historyczną narrację ukazującą różne aspekty kulturalnego, gospodarczego i politycznego wkładu Wielkiej Brytanii we współczesny świat. Pokaz uwzględniał sekcje związane z rewolucją przemysłową, narodową opieką zdrowotną, sztuką i wyna-

${ }^{46}$ I. MacRury, G. Poynter, 'Team GB'..., s. 2962.

${ }^{47}$ S. Zhou, B. Shen, C. Zhang, X. Zhong, Creating a Competitive Identity: Public Diplomacy in the London Olympics and Media Portrayal, w: The Global Impact of Olympic Media at London 2012, red. A. C. Billings, A. M. Hardin, Abingdon 2015, s. 24.

${ }^{48}$ C. R. Choi, C. M. Heo, Economic Changes Resulting from Seoul 1988: Implications for London 2012 and Future Games, „The International Journal of the History of Sport” 2013, vol. 30, nr 15, s. 1859.

49 J. Grix, B. Houlihan, Sports Mega-Events..., s. 586-587. 
lezieniem World Wide Web ${ }^{50}$. Motyw „Wyspy Cudów” ujawniał brytyjską dumę z ich kultury, uwzględniając literaturę, muzykę pop, film i historię. Nawiązano do rewolucji przemysłowej, Shakespeara, Churchilla, Thatcher, Beatlesów czy Harry'ego Pottera ${ }^{51}$. Kluczowym motywem prezentowanym podczas ceremonii otwarcia było zatem dziedzictwo kulturalne Wielkiej Brytanii, a zatem jeden z elementów wizerunku kraju, który uznano za priorytetowy w odniesieniu do całych igrzysk.

RIO DE JANEIRO 2016

Letnie igrzyska olimpijskie w Rio de Janeiro nie należały do silnie upolitycznionych, szczególnie biorąc pod uwagę ich niedawnych letnich poprzedników. I w tym przypadku można jednak doszukać się szeregu akcentów zasługujących na interpretację z perspektywy politologicznej. W pierwszej kolejności tyczy się to kwestii przyznania prawa organizacji tych igrzysk brazylijskiemu miastu. Współcześnie bowiem fakt wygrania danego miasta $\mathrm{w}$ wyścigu o prawo organizacji igrzysk wiązane jest niekiedy $\mathrm{z}$ atrybutami dyplomatycznymi politycznych przywódców państw. Analizując wybór gospodarza igrzysk w 2016 roku A. F. Cooper stwierdził, iż prezydent Brazylii Luiz Lula da Silva pokonał Baracka Obamę ${ }^{52}$, nawiązując do faktu, iż jednym z kontrkandydatów Rio było amerykańskie Chicago, a obaj prezydenci osobiście lobbowali za kandydaturami miast leżących w rządzonych przez nich krajach podczas Sesji MKOl w Kopenhadze w 2009 roku $^{53}$. Co więcej, w lobbowaniu brali udział także przywódcy państw, w których leżały pozostałe miasta kandydujące Madryt i Tokio - premierzy Japonii i Hiszpaniii ${ }^{54}$. Można tu zatem dostrzec podobną sytuację jak podczas przyznania prawa organizacji igrzysk letnich w 2012 roku, kiedy także polityczni przywódcy państw angażowali się we wspieranie poszczególnych kandydatur.

W trakcie igrzysk olimpijskich w Rio de Janeiro można było dostrzec także pewien gest Międzynarodowego Komitetu Olimpijskiego, któremu z całą pewnością można przypisać polityczny wydźwięk. Chodzi mianowicie o dopuszczenie do igrzysk drużyny uchodźców. Biorąc pod uwagę kryzys uchodźczy, jaki aktualnie

${ }^{50}$ M. R. G. Pope, Public diplomacy..., s. 1124-1125.

${ }^{51}$ J. A. Mangan, G. Ok, Y. M. Kwak, East Reflects on West, East Meets West!: South Korean Media Responses to London 2012, „The International Journal of the History of Sport” 2013, vol. 30, $\mathrm{nr} 15$, s. 1845.

52 A. F. Cooper, The Changing Nature of Diplomacy, w: The Oxford Handbook of Modern Diplomacy, red. A. F. Cooper, J. Heine i R. Thakur, Oxford 2013 s. 38.

${ }^{53}$ P. Radford, S. Grudgings, Rio wins 2016 Games as IOC rebuffs Obama, Reuters, 02.10.2009, http://www.reuters.com/article/us-olympics-idUSTRE58S1H820091002, dostęp 28.02.2017.

${ }^{54}$ J. Boykoff, Power Games. A Political History of the Olympics, London 2016, s. 211. 
ma miejsce na świecie, Narodowe Komitety Olimpijskie zostały poproszone przez MKOl o zidentyfikowanie sportowców-uchodźców, którzy mieliby potencjał do zakwalifikowania się na igrzyska olimpijskie. W ten sposób wytypowano 43 kandydatów, którzy zostali następnie poddani selekcji biorąc pod uwagę poziom sportowy, oficjalny status uchodźcy potwierdzony przez ONZ oraz osobistą sytuację. Wytypowano w ten sposób 10 sportowców, którzy wzięli udział w igrzyskach w Rio jako Olimpijska Drużyna Uchodźców (oryg. Refugee Olympic Team), której symbolami zostały olimpijskie flaga i hymn. Ich przygotowania i sprzęt zostały sfinansowane z programu MKOl Solidarność Olimpijska. Jak powiedział Prezydent MKOl Thomas Bach, „ci uchodźcy nie mają domu, drużyny, flagi, hymnu narodowego. Oferujemy im dom w wiosce olimpijskiej wspólnie ze sportowcami z całego świata. (...) Będzie to symbol nadziei dla wszystkich uchodźców na świecie" ${ }^{55}$. Cała koncepcja została zainicjowana przez prezydenta MKOl na forum Zgromadzenia Ogólnego ONZ w 2015 roku, zaś już po igrzyskach Sekretarz Generalny ONZ Ban Ki-moon podziękował Międzynarodowemu Komitetowi Olimpijskiemu za całą inicjatywę ${ }^{56}$. Ten symboliczny gest zwraca jednocześnie uwagę na polityczną i dyplomatyczną rolę, jaką można przypisać Międzynarodowemu Komitetowi Olimpijskiemu. Zwracając uwagę na kwestie społeczne MKOl w oczywisty sposób angażuje się w istotny pod względem politycznym problem. Co więcej, krok ten można uznać za przejaw sportowej pomocy rozwojowej, wykorzystującej pozytywne społeczne funkcje sportu. Sportowa pomoc rozwojowa należy do typowych technik prowadzenia dyplomacji publicznej przez państwa, zatem i w tym przypadku aktywność międzynarodowa MKOl przypomina w pewnym stopniu działalność państw.

\section{KONKLUZJE}

W niniejszym artykule dokonana została analiza odbywających się w XXI wieku letnich igrzysk olimpijskich z perspektywy ich politycznej roli. Pod tym względem z całą pewnością na pierwszy plan wysuwają się igrzyska w Pekinie w 2008 roku. Celem ich organizacji było kształtowanie pożądanego wizerunku międzynarodowego komunistycznych Chin. Co więcej, fakt iż „oczy świata” były zwrócone wówczas na Chiny, wykorzystywany został przez krytyków niedemokratycznego reżimu w Pekinie, którzy organizowali szereg protestów. Pozostałe, XXI-wieczne

${ }^{55}$ REFUGEE OLYMPIC TEAM TO SHINE SPOTLIGHT ON WORLDWIDE REFUGEE CRISIS, MKOl, 03.06.2016, https://www.olympic.org/news/refugee-olympic-team-to-shine-spotlight-onworldwide-refugee-crisis, dostęp 28.02.2017.

${ }^{56}$ UN SECRETARY-GENERAL PRAISES INTERNATIONAL OLYMPIC COMMITTEE FOR REFUGEE OLYMPIC TEAM, MKOl, 20.09.2016, https://www.olympic.org/news/un-secretary-generalpraises-international-olympic-committee-for-refugee-olympic-team, dostęp 28.02.2017. 
letnie igrzyska olimpijskie odbiegały od nich pod względem upolitycznienia w sposób zdecydowany, aczkolwiek one także nie obyły się bez politycznych konotacji. W szczególności jest to związane z rolą sportu w dyplomacji publicznej, a co za tym idzie użytecznością mega-wydarzeń sportowych w kształtowaniu wizerunku narodowego. Właściwie wszystkie współczesne igrzyska olimpijskie w pewnym stopniu mają na celu przeciwdziałanie negatywnym stereotypom na temat kraju w którym się odbywają, przyciąganie turystów, inwestorów itp. Spośród analizowanych zawodów, obok igrzysk w Pekinie było to szczególnie widoczne podczas igrzysk w Londynie.

Politycznego znaczenia współczesnych igrzysk olimpijskich nie ogranicza się oczywiście do ich roli w brandingu narodowym. Przykładowo zagrożenie terrorystyczne determinuje sposób, w jaki organizatorzy igrzysk przygotowują się do nich. Igrzyska olimpijskie są także areną symbolicznych prób zbliżenia pomiędzy skonfliktowanymi narodami, jak w przypadku wspólnego marszu reprezentacji Korei Północnej i Południowej podczas igrzysk w Atenach, a także innych symbolicznych gestów o zabarwieniu politycznym, jak udział w igrzyskach w Rio de Janeiro drużyny uchodźców. Ostatni przypadek zwraca zarazem uwagę na polityczną rolę Międzynarodowego Komitetu Olimpijskiego.

Na podstawie powyższych obserwacji można stwierdzić, iż koniec zimnej wojny nie oznaczał końca upolitycznienia sportu. XXI-wieczne igrzyska olimpijskie pokazują, iż polityka w dalszym ciągu jest obecna w międzynarodowym sporcie. Niewiele wskazuje przy tym, iż sytuacja ta ulegnie w najbliższym czasie zmianie. Mega-wydarzenia sportowe $\mathrm{w}$ dalszym ciągu będą wykorzystywane w celach wizerunkowych, natomiast malejące zainteresowanie organizacją igrzysk olimpijskich, jakie można zaobserwować w ostatnim czasie, będzie zmuszało MKOl do przyznawania ich miastom leżącym na terenie państw niedemokratycznych. Zatem mimo że nastanie multilateralnego świata zmieniło w pewnym stopniu oblicze upolitycznienia sportu, to z całą pewnością nie doprowadziło do separacji sportu i polityki.

\section{BIBLIOGRAFIA}

Ateny 2004, PKOl, http://www.olimpijski.pl/pl/251, ateny-2004.html.

Bairner A., Molnar G., The politics of the Olympics: An Introduction w: The Politics of the Olympics. A Survey, red. A. Bairner, G. Molnar, London 2010, s. 3-14.

BOCOG, Preparation for the Games: New Beijing Great Olympics. Official Report of the Beijing 2008 Olympic Games, vol. III.

Bonde H., Sport, the Olympics and Politics: European Responses to Beijing 2008, „The International Journal of the History of Sport" 2009, vol. 26, nr 10, s. 1555-1570.

Boykoff J., Power Games. A Political History of the Olympics, London 2016.

Brady A-M., The Beijing Olympics as a campaign of mass distraction, w: China's Thought Management, red. A-M. Brady, Abingdon 2012, s. 1-24. 
Brownell S., The Beijing Olympics as a Turning Point? China's First Olympics in East Asian Perspective, „The Asia-Pacific Journal. Japan Focus” 2009, vol. 7, zeszyt 23, nr 4, s. 185-204.

Cha V. D., Beyond the Final Score. The Politics of Sport in Asia, New York 2009.

Cha V. D., Politics and the Olympic Transaction: Measuring China's Accomplishments, „The International Journal of the History of Sport" 2001, vol. 27, nr 14-15, s. 2359-2379.

Choi C. R., Heo C. M., Economic Changes Resulting from Seoul 1988: Implications for London 2012 and Future Games, „The International Journal of the History of Sport” 2013, vol. 30, nr 15, s. 1854-1866.

Cooper A. F., The Changing Nature of Diplomacy, w: The Oxford Handbook of Modern Diplomacy, red. A. F. Cooper, J. Heine i R. Thakur, Oxford 2013, s. 35-53.

d'Hooghe I., The Limits of China's Soft Power in Europe. Beijing's Public Diplomacy Puzzle, The Hague 2010.

deLisle J., "One World, Different Dreams": The Context to Define the Beijing Olympics, w: Owing the Olympics. Narratives of the New China, red. M. E. Price, D. Dayan, Ann Arbor 2008, s. 17-66.

Galily Y., Tamir I., Levy M., The games must go on? The influence of terror attacks on hosting sporting events in Israel, „Israel Affairs” 2012, Vol. 18, No. 4, s. 629-644.

Gries P. H., Crowson H. M., Sandel T., The Olympic Effect on American Attitudes towards China: beyond personality, ideology, and media exposure, „Journal of Contemporary China” 2010, nr 19 (64), s. 2130-231.

Grix J., Brannagan P. M., Houlihan B., Interrogating States' Soft Power Strategies: A Case Study of Sports Mega-Events in Brazil and the UK, „Global Society” 2015, vol. 29, nr 3, s. 463-479.

Grix J., Houlihan B., Sports Mega-Events as Part of a Nation's Soft Power Strategy: The Cases of Germany (2006) and the UK (2012), „The British Journal of Politics and International Relations" 2014, vol. 16, s. 572-596.

Hong F., Zhouxiang L., The Politicisation of Sport in Modern China. Communists and Champions, London 2013.

Horne J., Houlihan B., London 2012, w: Leveraging Legacies from Sports Mega-Events. Concepts and Cases, red. J. Grix, London 2014, s. 107-117.

Horne J., Whannel G., Understanding the Olympics, London 2012.

Houlihan B., Tan T-C., Park J., The national government perspective, w: Routledge Handbook of Sports Event Management, red. M. M. Parent, J-L. Chappelet, London 2015, s. 289-305.

House of Commons Foreign Affairs Committee, FCO Public Diplomacy: The Olympic and Paralympic Games 2012, Second Report of Session 2010-11, London 2011.

International Olympic Committee, Factsheet. Beijing Facts and Figures, August 2009, https:// www.olympic.org/olympic-legacy/ /media/A8264DD681D34B459B026CBD6FFD4D78.ashx.

Krawczyk Z., Sport in changing Europe, w: Sports Involvement in Changing Europe, red. J. Kosiewicz, K. Obodyński, Rzeszów 2004.

Lai Lee A., Did the Olympics help the nation branding of China? Comparing public perception of China with the Olympics before and after the 2008 Beijing Olympics in Hong Kong, „Place Branding and Public Diplomacy" 2010, vol. 6, nr 3, s. 207-221.

Latham K., Unimagined China: Media, Technologies and the Fragmentation of National Olympic Audiences, „The International Journal of the History of Sport” 2012, vol. 29, nr 16, s. 2311-2325.

Londres 2012. Rapport officiel des Jeux Olympiques, vol 1, London 2012.

Lu Y-N., The Representation of the 2008 Beijing Olympic Games: The Rise of China's Soft Power, w: China's Quiet Rise. Peace Through Integration, red. B. Guo, C-C. Teng, Lanham 2011 s. 29-40.

MacRury I., Poynter G., 'Team GB' and London 2012: The Paradox of National and Global Identities, „The International Journal of the History of Sport” 2010, vol. 27, nr 16-18, s. 2958-2975. 
Mangan J. A., Kim H.-D., Cruz A., Kang G.-H., Rivalries: China, Japan and South Korea-Memory, Modernity, Politics, Geopolitics - and Sport, „The International Journal of the History of Sport" 2013, vol. 30, nr 10, s. 1130-1152.

Mangan J. A., Ok G., Beijing 2008: Symbolic Hegemonic Assertion? South Korean Media Reactions and Responses to the Chinese Olympics, „The International Journal of the History of Sport" 2010, vol. 27, nr 14-15, s. 2440-2466.

Mangan J. A., Ok G., Kwak Y. M., East Reflects on West, East Meets West!: South Korean Media Responses to London 2012, „The International Journal of the History of Sport” 2013, vol. 30, nr 15, s. $1834-1853$.

Mateša Z., Wydarzenia sportowe jako kluczowy element przełamywania barier, [w:] Sport i Dyplomacja, Polski Komitet Olimpijski, Warszawa 2015.

Pan C., Problematizing "Constructive Engagement" in EU-China Policy, w: Europe and China: Strategic Partners or Rivals?, red. R. Vogt, Hong Kong 2012, s. 37-57.

Pigman G. A., International Sport and Diplomacy's Public Dimension: Governments, Sporting Federations and the Global Audience, „Diplomacy \& Statecraft” 2014, nr 25, s. 94-114.

Pope M. R. G., Public diplomacy, international news media and London 2012: cosmopolitanismTM, „Sport in Society”, 2014, vol. 17, nr 9.

Qing L., Encoding the Olympics - Visual Hegemony? Discussion and Interpretation on Intercultural Communication in the Beijing Olympic Games, „The International Journal of the History of Sport" 2010, vol. 27, nr 9-10, s. 1824-1872.

Radford P., Grudgings S., Rio wins 2016 Games as IOC rebuffs Obama, Reuters, 02.10.2009, http:// www.reuters.com/article/us-olympics-idUSTRE58S1H820091002.

REFUGEE OLYMPIC TEAM TO SHINE SPOTLIGHT ON WORLDWIDE REFUGEE CRISIS, MKOl, 03.06.2016, https://www.olympic.org/news/refugee-olympic-team-to-shine-spotlighton-worldwide-refugee-crisis.

Rofe J. S., It is a squad game: Manchester United as a diplomatic non-state actor in international affairs, „Sport in Society” 2014, s. 1-19.

Sydney Organising Committee for the Olympic Games, Official Report of the XXVII Olympiad. Preparing of the Games, vol. I, Sydney 2001.

Taylor T., Toohey K., Perceptions of Terrorism Threats at the 2004 Olympic Games: Implications for Sport Events, „Journal of Sport \& Tourism” 2007, nr 2(12), s. 55-114.

Thompson D., Beijing Olympics: More at Stake than Gold Medals, „chinabusinessreview.com”, January-February 2008.

Tomlinson A., Lording It. London and the getting of the Games w: Watching the Olympics. Politics, power and representation, red. J. Sugden, A. Tomlinson, London 2012, s. 1-17.

Tomlinson R., Bass O., Bassett T., Before and after the vuvuzela: identity, image and mega-events in South Africa, China and Brazil, „South African Geographical Journal” 2011, vol. 93, nr 1, s. 33-48.

Toohey K., Taylor T., Mega Events, Fear, and Risk: Terrorism at the Olympic Games, „Journal of Sport Management" 2008, nr 22, s. 451-469.

UN SECRETARY-GENERAL PRAISES INTERNATIONAL OLYMPIC COMMITTEE FOR REFUGEE OLYMPIC TEAM, MKOl, 20.09.2016, https://www.olympic.org/news/un-secretary-generalpraises-international-olympic-committee-for-refugee-olympic-team.

Zeng G., Go F., Kolmer C., The impact of the 2008 Summer Olympic Games on Beijing's and Chinas's image, w: Global Sport Marketing. Contemporary issues and practice, red. M. Desbordes, A. Richelieu, London 2012, s. 56-80.

Zhang Q., Sports Diplomacy: The Chinese Experience and Perspective, „The Hague Journal of Diplomacy" 2013, nr 8, s. 211-233. 
Zhou S., Shen B., Zhang C., Zhong X., Creating a Competitive Identity: Public Diplomacy in the London Olympics and Media Portrayal, w: The Global Impact of Olympic Media at London 2012, red. A. C. Billings, A. M. Hardin, Abingdon 2015, 23-41.

\section{Streszczenie}

Artykuł ma na celu przegląd odbywających się w XXI wieku letnich igrzysk olimpijskich z perspektywy ich upolitycznienia. W badaniu uwzględniono igrzyska olimpijskie w Atenach w 2004 roku, w Pekinie w 2008 roku, w Londynie w 2012 roku oraz w Rio de Janeiro w 2016 roku. Za najbardziej upolitycznione uznano igrzyska w Pekinie, aczkolwiek w trakcie każdej z tych imprez sportowych można było dostrzec polityczne elementy. W artykule podjęto próbę odpowiedzi na pytanie badawcze dotyczące tego, czy po zakończeniu zimnej wojny w dalszym ciągu sport w dalszym ciągu odgrywa istotną rolę polityczną.

Słowa kluczowe: Igrzyska olimpijskie, sport, polityka, upolitycznienie sportu

\section{POLITICS OF SPORT IN THE 21ST CENTURY AS OF THE EXAMPLE OF OLYMPIC SUMMER GAMES}

\section{Su m m a ry}

The aim of the article is to assess the 21st Century Olympic Summer Games from the perspective of their interconnection with politics. The research included Olymics in Athens in 2004, Beijing in 2008, London in 2012 and Rio de Janeiro in 2016. The Games in Beijing have been assessed the most politicized within the analysed period, however each of the sports events have somehow collided with politics. The main research question concerned was whether after the end of the Cold War sport has remained its former political role in international relations.

Keywords: Olympic Games, sport, politics, poltics on sport 